\title{
A Review of Literature on the Determinants of the Stock Market Performance and it Company's Performance
}

\author{
Noor Afza' ${ }^{1}$ and Poornima. $\mathrm{P}^{2}$ \\ ${ }^{1}$ Professor \& Dean, Department of Commerce \& Management, Tumkur University, Tumkur \\ ${ }^{2}$ Research Scholar, Tumkur University, Tumkur
}

\section{ABSTRACT}

The study aims at reviewing and discovering the existing empirical evidence regarding the stock market performance and IT investments. The significant analysis of the statistical tools used is out of the purview of this study. The performance of the stock market is analyzed through the determinants of the stock market which is broadly classified into macroeconomic factors like Gross Domestic Product (GDP), GNP, Inflation Rate, Exchange Rate, and Interest Rate; and institutional factors like income inequality, legal environment, political, and financial liberalization. Also, to measure the performance of the IT company, indicators like Price earning ratios, dividend yield, Earnings Per Share, and Return on Equity are considered.

KEY WORDS: IT INVESTMENTS, EPS, DIVIDEND YIELD, CORPORATE GOVERNANCE, EXCHANGE RATE, STOCK MARKET, FINANCIAL LIBERALISATION.

\section{INTRODUCTION}

A stock market, equity market, or share market is the aggregation of buyers and sellers of stocks (also called shares), which represent ownership claims on businesses. Participants in the stock market range from small individual stock investors to larger investors, who can be based anywhere in the world, and it also includes banks, insurance companies, pension funds, and hedge funds. Their buy or sell orders may be executed on their behalf by a stock exchange trader. So, investors should analyze the stock market performance and the IT company's performance. Among other sectors, the IT industry is at a robust speed which lures the investors to invest in the

\section{ARTICLE INFORMATION}

Received 12th Oct 2020 Accepted after revision 20th Dec 2020 Print ISSN: 0974-6455 Online ISSN: 2321-4007 CODEN: BBRCBA

Thomson Reuters ISI Web of Science Clarivate Analytics USA and Crossref Indexed Journal

\section{Clarivate
Analytics}

NAAS Journal Score 2020 (4.31)

A Society of Science and Nature Publication,

Bhopal India 2020. All rights reserved.

Online Contents Available at: http//www.bbrc.in/

Doi: http://dx.doi.org/10.21786/bbrc/13.15/25 stock market with a motive of earning higher returns from their investment.

The paper instigates the discussion on the review of the literature regarding determinants of the stock market performance which is classified into macro-economic factors and institutional factors; and the indicators of the IT company's performance.

\section{Determinants of Stock Market Performance:}

Researchers have conducted studies on the empirical literature of determinants of stock market performance. So, to investigate the determinants of stock market performance, three factors are considered i.e., macroeconomic factors, institutional factors, and a combination of both the factors.

\subsection{Macro-Economic Factors}

2.2 This Section Covers The Reviews Of The Empirical Literature On The Macro-Economic Factors Like Inflation Rate, Exchange Rate, Money Supply, Industrial Production, The Wholesale Price Index, Gnp, Fdi, And Gdp Are Studied 
- P.Shrestha, Biggyan Raj Subedi (2014) has conducted an empirical study on determinants of stock market performance in Nepal. The study has also assessed the impact of major changes in politics and Nepal Rastra Bank's policy on lending against share collateral. Using OLS estimations of behavioral equations the empirical results have obtained by indicating that the performance of the stock market is positive to inflation and broad money growth, and negative to the interest rate. That study suggests that investors have taken equity as a hedge against inflation and believe stock as an alternative financial instrument. In addition to that, Nepalese stock market performance is also stimulated by the availability of liquidity and low-interest rates. To conclude, the stock market has significantly responded to changes in the political environment and the policy of Nepal Rastra Bank.

- John, E. (2019), has examined how macro-economic variables affect the stock market performance in Nigeria with four macroeconomic variables - money supply, interest rate, exchange rate, and inflation rate as independent variables and market capitalization as the dependent variable. It was found that money supply and interest rates are the two factors influencing the stock market performance in Nigeria as they exhibit a significant effect on stock market performance, whereas exchange rate and inflation rate indicate a weak performance of the stock market.

- Gan, C., Lee, M., Yong, H., and Zhang, J. (2006) conducted a study on the relationships between New Zealand and stock market index and a set of seven macroeconomic variables using the Granger causality test and co-integration. It was found that there was a long-run relationship between New Zealand's stock market index and the macroeconomic variables. Also, it was revealed that the New Zealand stock index was not a leading indicator for changes in macroeconomic variables though it indicated consistently determined by the interest rate, money supply, and real GDP.

- Robert, D.G. (2008) investigated the effect of two macroeconomic variables (the exchange rate and oil price) on stock market returns of emerging economies, namely, Brazil, Russia, India, and China. It was found that there was no significant relationship between present and past market returns with macroeconomic variables and indicated a weak form of efficiency for the four emerging economies. Also, it cleared that there was no significant relationship between the exchange rate and oil price on the stock market index of these four countries.

- Bhattacharyya, B. and Mukherjee, J. (2006) have examined the Indian stock market and seven macroeconomic variables relationship by using the VAR framework, Toda, and Yamamoto non- Granger causality tests. It was found from the study that there was no linkage between stock returns and money supply, index of industrial production, GNP, real effective exchange rate, foreign exchange reserves, and trade balance, also bi-directional causality between stock return and rate of inflation was observed.

- Latha, K., Gupta, S., \& Kumar, A. (2016) examined the short and long-run dynamic relationship between the Indian Stock Index and Major Macroeconomic variables, viz. GDP, Inflation, Interest Rate, Exchange Rate, Money Supply, and International Oil Prices. It was found that the Indian Stock Index is cointegrated with Money Supply, GDP, and Inflation. ARDL model evidenced a significant positive relation with contemporaneous GDP and significant negative relation with own lagged values; lagged values of interest rate and long-run money supply. Investors and stock market analysts can search for the presence of exploitable arbitrage opportunities in the Indian market to earn above-normal returns by formulating long-run investment strategies based on GDP, Money Supply, and Inflation.

- Naik, P., \&t Padhi, P. (2012) investigates the relationships between the Indian stock market index (BSE Sensex) and five macroeconomic variables, namely, industrial production index, wholesale price index, money supply, treasury bills rates, and exchange rates. The analysis reveals that macroeconomic variables and the stock market index are co-integrated by indicating a long-run equilibrium relationship exists between them. It is observed that the stock prices positively relate to the money supply and industrial production but negatively relate to inflation. The exchange rate and the short-term interest rate are found to be insignificant in determining stock prices. But in the Granger causality test macroeconomic variables causes the stock prices in the long-run as well as in the short-run.

- Sur, D., Et Bhunia, A. (2015) examined the influence of selected macroeconomic variables in terms of international crude oil price, exchange rates, domestic gold price, real interest rates, and wholesale price index on stock market indices (Sensex and Nifty) of India. With the help of time series, monthly data was collected from Reserve Bank of India database; BSE and NSE database, investing.com and yahoo, finance database for the period July 1997 to July 2015 with the application of financial econometrics. It was found that Sensex and Nifty reactions to shocks on crude oil prices, exchanges rates, real interest rates, and wholesale prices indices were positive while a negative shock from Sensex and Nifty to real interest was noticed.

- Jeffus (2004), has examined the relationship between the FDI and stock market in selected Latin American countries. It is found that FDI and stock market development are highly and positively correlated and FDI is a predictor of stock market growth. So, he argues that when firms enter into a new market, they may seek to raise additional capital through the local stock market. This enhances the local stock market.

- Alexander Owiredu, M. Oppong, Sandra A Asomaning (2016) examines the macroeconomic determinants of stock 
market development in Ghana by using annual secondary data from Bank of Ghana Quarterly Economic Bulletins, Ghana Statistical Service, Ghana Stock Exchange Market Statistics, the World Bank and IMF's International Financial Statistics. The macroeconomic indicators such as the real income (GDP per capita income), domestic saving, stock market liquidity, financial intermediary growth, macroeconomic stability (inflation), and private capital flows with stock market capitalization used as a proxy for the study were collected and used for the analysis. These variables were examined to establish a relationship with stock market developments based on a linear regression model.

The regression analysis found stock market liquidity to be statistically significant to stock market developments as opposed to the other determinants (such as macroeconomic stability (inflation) real income and domestic savings and private capital flows) which were found to be nonsignificant. This result suggests that macroeconomic stability (inflation), real income, domestic savings, and private capital flows proved not to have any significant impact on stock market development since their regression coefficients were not statically significant at the $5 \%$ level of significance.

2.3 Institutional Factors: Along with the studies on the impact of macroeconomic factors on stock market performance, there are also studies conducted on the relationship between institutional factors and stock market performance. So in this section, the empirical literature on institutional factors like income inequality, legal environment, political, and financial liberalization are examined.

- Ameer, R. (2010) has conducted an empirical study to assesses the overall economic performance of South East Asian countries has remarked in the 1990s concerning significant increase in economic development and focusing on the impact of foreign direct investment, trade openness, financial liberalization, and institutional developments on the income equality and social welfare. It was found that the households' income shares (or income inequality) were affected by foreign direct investment and trade openness for 1991-2004 and the stock market liberalization and institutional developments have increased the income share of only the high-income group. It was also observed that trade openness and population demographics were significant welfare-enhancing determinants of social expenditure, whereas, financial liberalization and foreign official loans were significant welfare reducing factors.

- Reuveny, R., \&t Li, Q. (2003) has conducted a systematic statistical study of the effects of both economic openness and democracy on income inequality. To measure the national income inequality the researcher has used a comprehensive Gini coefficient data set. Economic openness is measured from trade flows, foreign direct investment inflows, and financial capital inflows. The period studied is 1960 to 1996 with a sample of
69 countries. It was found that democracy and trade reduce income inequality, foreign direct investments increase income inequality, and financial capital does not affect income inequality. Hence, policy implications are discussed.

- La Porta (1998) has analyzed the legal rules which cover the protection of corporate shareholders and creditors. The origin of these rules and the quality of their enforcement can be seen in 49 countries around the world. It was found that the legal tradition influences the degree of protection of creditors and shareholders, and the efficiency of contract enforcement, thereby affecting financial market development.

- Pistoret (2000) has examined a comprehensive analysis of legal change in the shareholder protection and creditor rights in 24 transition economies from 1992 to 1998 and its effect on the propensity of firms to raise external finance. It was found that not only the quality of legal frameworks but also the effectiveness of legal institutions are important for financial market development. Hence, the effectiveness of legal institutions has a stronger impact on external finance when compared with the law on the books, even though there is a substantial improvement in shareholder and creditor rights.

- Bayar, Y. (2016) has investigated the impact of institutional development on stock market development in 8 European Union transition economies during the 2002-2013 period by employing a panel regression method. It was found that political stability, regulatory quality, rule of law, and control of corruption had a positive impact on stock market development.

- Julio, B., \&t Yook, Y. (2012) has documented the cycles in corporate investment corresponding with the timing of national elections around the world. During election years, firms reduce investment expenditures by an average of $4.8 \%$ relative to nonelection years by controlling for growth opportunities and economic conditions. The magnitude of the investment cycles varies with different country and election characteristics. So, the researcher has investigated several potential explanations and found evidence for supporting the hypothesis that political uncertainty leads firms to reduce investment expenditures until the electoral uncertainty is resolved. It was found that political uncertainty is an important channel through which the political process affects real economic outcomes.

- R. Paudel, N. Perera (2009) has examined the role of financial liberalization on money demand and economic growth by employing the ARDL(Autoregressive distributed Lag) approach of cointegration in Sri Lankan data from 1963 to 2006. It was found that financial liberalization has a significant negative impact on narrow and broad money demand in the long-run, while such impact is found to be positive in the short-run but not significant; and there was a significant positive impact in the short-run on broad money. In the case of economic 
growth, financial liberalization has played a positive role but not significant, while in the short-run the relation is found to be negative.

\subsection{Combination of Macroeconomic and Institutional Factors}

- Islam, F.T., Mostofa, M.S., \& Tithi, A.A. (2017) conducted a study on the institutional and macroeconomic determinants of stock market performance using data in the last 20 years starting from 1995 to 2015. Gross Domestic Product (GDP), Consumer Price Index (CPI), inflation rate, and Foreign Direct Investment (FDI) inflows were used as the proxy of macroeconomic determinants, whereas market capitalization, the total issued capital and market turnover of Dhaka Stock Exchange was the proxy of institutional determinants of capital market performance. Both descriptive and inferential statistics are used to identify the determinants and their significance in capital market development. It was found that both institutional and macroeconomic variables significantly influence the capital market performance. Whereas, CPI and GDP as macroeconomic determinants and Total Market Capitalization as institutional determinants were found significant based on their coefficient value in the ordinary least square multiple regression analysis.

- Yartey (2007) has examined the macroeconomic and institutional determinants of stock market development in 13 African countries. It was found that the income level, domestic savings and investment, financial intermediary development, and stock market liquidity had a positive impact on stock market development in Africa. In addition to it, institutional quality - which consists of corruption, law, and order, bureaucratic quality, democratic accountability, and government stability - to be an important determinant in fostering stock market development in Africa.

- Cherif, M., \&t Gazdar, K. (2010) in their paper on the influence of the macroeconomic environment and institutional quality on stock market development has provided new evidence by using data from 14 MENA (the Middle East and North Africa) countries from 1990-2007. With the help of panel data and instrumental variable techniques, it was found that income level, saving rate, stock market liquidity, and interest rate influence stock market development with the expected theoretical signs. Also, it showed that banking and the stock market sectors are complementary instead of being substitutes. It was also found that the institutional environment is captured by a composite policy risk index which does not appear to be a driving force for the stock market capitalization in the region.

- Matadeen, J. (2019) has investigated a paper on the macroeconomic and institutional determinants of stock market development in Mauritius during the period 1989-2016 through a dynamic vector error correction model. It was found that macroeconomic factors such as economic growth, banking sector development, stock market liquidity, and gross fixed capital formation are important drivers of stock market development on the island. Additionally, political stability, rule of law, government effectiveness, voice accountability, and control of corruption also play a key role in terms of enhancing stock market development.

\section{Indicators of the it Company's Performance}

- Rosa, A.C., Mello, C.H., Chimendes, V.C., Andrade, H.S., \& Amorim, G. (2019) has addressed in their paper the difficulties in researching innovation and Open Innovation (OI) performance metrics through exploratory literature research followed by a survey conducted with small technology-based enterprises incubated at important Brazilian industrial and technological centers. Small business entrepreneurs and managers are well known for the idea of OI practices are still restricted to large corporations. The indicators proposed are developed with the support of the statistical technique of factorial analysis which has been proved to be the most significant to measure OI with the company and it has been possible to understand that a small company can successfully use 0I. Even though it is not common today, it should be encouraged.

- Stores, F. S. (2015) analyzed the relationship between IT investment and the firm's financial performance in Malaysian Public Listed Companies. Firm performance was measured by revenue, return on investment (ROI), and return on assets (ROA). A panel data analysis was applied to the data observed from 2009 to 2012 with a sample of 90 firms via annual reports. It was found that regressing return on investment against IT investment indicates that there is a relationship between IT investment and return on investment. However, the result of the regressing return on assets and revenue indicates that there is no relationship between IT investment and return on assets, IT investment, and revenue respectively. To conclude, the analysis provides useful implications for managers to better understand the relationship between IT investment and firms' performance so that they can make wiser decisions to maximize the business value of their investments.

- Hui-Shan Lee, Wai-Mun Har, Sin-Yee Lee (2016) conducted a study on the profitability determinants of information technology software companies in Malaysia with intangible assets included as an important independent variable. Other variables used are profitability (ROA), change of total revenues, opportunities growth, past earning growth, and size. It was found that all independent variables have a positive and significant relationship with profitability except the relative size of the firm variable. A negative result between size and profitability could be due to the role of flexibility by smaller size software firms to transform rapidly as the peripheral business surroundings change. To conclude, it is unnecessary to expand the size of the firms in achieving prosperous profit. Moreover, engagement in innovative intangibility can enhance the competitive capability and reputation of software firms, hence it will improve firms' profitability. 
- Jahangir Chauhan, Mohd Shamim Ansari, Mohd Taqi, Mohd Ajmal (2019) has investigated the impact of dividend policy on the profitability of Indian Information Technology (IT) companies listed on the Bombay Stock Exchange. Companies were selected for the study based on market capitalization. Correlation matrix and panel regression model were used for testing of hypotheses. It was found that the selected companies do not follow a consistent pattern of dividend payments and the association between Price Earning Ratio (PER) and Dividend Payout Ratio (DPR) was low positive. Also, there is a strong relation between ROE-ROA. Hausman Test reveals that the random effect model is appropriate thereby indicating that the performance of selected companies has a significant impact on the dividend policy of selected companies. The dividend policy is still regarded as one of the complicated areas in corporate finance.

- N.Shin (2001) has examined the empirical contribution of IT to financial performance as measured by net profit, ROA, and ROE by focusing on the alignment of IT with business strategies such as vertical disintegration and diversification. It was found that IT does not directly improve financial performance. In conjunction with vertical disintegration and diversification, however, it does improve financial performance as measured by net profit. Financial performance ratios such as ROA and ROE are not correlated with the alignment (or interaction) factor of IT with vertical disintegration and diversification. To conclude, an increase in IT spending improves net profit, but not performance ratios such as ROA and ROE of firms with decreased vertical integration and higher diversification.

\section{CONCLUSION}

Stock markets can be volatile, and the reasons behind stocks rise and fall can be complex. Stock prices are affected by many factors like macroeconomic factors, institutional factors, and other factors that influence stock prices directly or indirectly. The empirical literature shows that macroeconomic variables such as inflation rate, exchange rate, money supply, industrial production, the wholesale price index, GNP, FDI, and GDP are important and have a positive impact on stock market development. Macroeconomic instability can adversely affect the development of the stock market. Moreover, institutional factors such as institutional quality, financial liberalization policies, political risk, law and order, and bureaucratic quality play major roles in the development of stock markets.

Financial indicators are a neutral tool for evaluating the company's performance. Investors are always searching for that one golden key measurement that can be obtained by looking at a company's financial statements. Although, investors should analyze these four main areas of financial health that should be examined are liquidity, solvency, profitability, and operating efficiency. Among the four, the best measurement of a company's health is the level of its profitability. However, no single metric can identify the overall financial and operational health of a company. Liquidity will tell you about a firm's ability to ride out the short-term rough patches and solvency will tell about longer-term debt and obligations. Whereas, efficiency and profitability say about its ability to convert inputs into cash flows and net income. All of these factors together are necessary to get a complete and holistic view of a company's stability.

\section{REFERENCES}

Ameer, R. (2010), Impact of Institutional Developments, Financial and Trade Openness on the Income Equality and Social Welfare in Southeast Asian Countries.

Bayar, Y. (2016), Institutional Determinants of Stock Market Development in European Union Transition Economies, The Romanian Economic Journal, 19, 211226.

Bhattacharyya, B. and Mukherjee, J. (2006), Indian Stock Price Movement and the Macroeconomic context - A Time Series Analysis, Journal of International Business and Economics, 5 (1): 167-181.

Cherif, M., \&t Gazdar, K. (2010), Macroeconomic and institutional determinants of stock market development in MENA region: new results from a panel data analysis, The International Journal of Banking and Finance, 7, 8.

Jahangir Chauhan, Mohd Shamim Ansari, Mohd Taqi, Mohd Ajmal, Dividend Policy and Its Impact on Performance of Indian Information Technology Companies, International Journal of Finance and Accounting, Vol. 8 No. 1, 2019, pp. 36-42. doi: 10.5923/j.ijfa.20190801.03.

John, E. (2019), Effect of Macroeconomic Variables on Stock Market Performance in Nigeria.

Julio, B., \&t Yook, Y. (2012), Political Uncertainty and Corporate Investment Cycles, Journal of Finance, 67, 45-83.

Gan, C., Lee, M., Yong, H. and Zhang, J. (2006), Macroeconomic Variables and Stock Market Interactions: New Zealand Evidence, Investment Management, and Financial Innovations, 3 (4): 89-101.

Hui-Shan Lee, Wai-Mun Har, Sin-Yee Lee (2016), Profitability Determinants of Information Technology Software Companies in Malaysia, American Scientific Publishers, USA, Vol. 4, 400-407, 2016.

Islam, F.T., Mostofa, M.S., \&t Tithi, A.A. (2017), Macroeconomic and Institutional Determinants of Capital Market Performance in Bangladesh: A Case of Dhaka Stock Exchange, International Journal of Academic Research in Accounting, Finance and Management Sciences, 7, 306-311.

Jeffus, W.(2004), FDI and stock market development in selected Latin American countries, International Finance Review 5: 35-44.

La Porta, R., Lopez-de-Silanes, F., Shleifer, A., and Vishny, R.W.(1998), Law and Finance, Journal of Political Economy 106: 1113-1155.

Latha, K., Gupta, S., \&t Kumar, A. (2016), Relationship 
between Indian Stock Market Performance and Macroeconomic Variables: An Empirical Study.

Matadeen, J. (2019), Stock Market Development: An Assessment Of Its Macroeconomic And Institutional Determinants In Mauritius, International Journal of Economics and Financial Issues, 9, 197-202.

N Shin (2001) The impact of information technology on financial performance: the importance of strategic choice, European Journal of Information Systems, 10:4, 227-236, DOI: 10.1057/palgrave.ejis.3000409

Naik, P., \& Padhi, P. (2012), Interaction of Macroeconomic Factors and Stock Market Index: Empirical Evidence from Indian Data. Econometric Modeling: International Financial Markets - Emerging Markets eJournal.

Paudel, R., \&t Perera, N. (2009), How does Financial Liberalisation Impact on Money Demand and Economic Growth? Evidence from Sri Lanka, Singapore Economic Review Conference 2009.

Pistor, K., Raiser, M., Gelfer, S.(2000), Law and finance in transition economies, Economics of Transition 8, 325-368.

Owiredu, A., Oppong, M., \&t Asomaning, S.A. (2016), Macroeconomic Determinants of Stock Market Development in Ghana.

Reuveny, R., \&t Li, Q. (2003), Economic Openness, Democracy, and Income Inequality, Comparative
Political Studies, 36, 575 - 601.

Robert, D.G. (2008), Effect of Macroeconomic Variables on Stock Market Returns for four Emerging Economies: Brazil, Russia, India and China, International Business Et Economics Research Journal, 7 (3): 1-8.

Rosa, A.C., Mello, C.H., Chimendes, V.C., Andrade, H.S., \& Amorim, G. (2019), Factorial Analysis as a tool to support the measurement of Open Innovation practices in Small Business in important Brazilian industrial centers. https://api.semanticscholar.org/ CorpusID:211776206

Shrestha, P., \&t Subedi, B.R. (2014), Determinants of Stock Market Performance in Nepal, NRB Economic Review, 26, 25-40.

Stores, F. S. (2015). The relationship between information technology (IT) investment and firm's financial performance of public listed companies in Malaysia (Doctoral dissertation, Universiti Tun Hussein Onn Malaysia).

Sur, D., \& Bhunia, A. (2015), Impact of Selected Macroeconomic Variables on Stock Market in India.

Yartey, C.A.(2007), Well-developed financial intermediary sector promotes stock market development: evidence from Africa, Journal of Emerging Market Finance 6(3): 269-89.

https://en.wikipedia.org/wiki/Stock_market 